\title{
In Pursuit of Relevance and Sustainability
}

\author{
Ole Jonny Klakegg*
}

Norwegian University of Science and Technology, Trondheim, Norway

\begin{abstract}
The starting point of this article is that the strategic dimension of projects concerns creating value. It shows that value is a complex issue that requires many difficult questions to be answered. A case project illustrates how project success may look very different from different perspectives. Further it is shown that relevance and sustainability are superior criteria that need to be secured for value creation to be possible. Some of the short-comings of current practices are illustrated and indications of main areas for improvement are given. The article suggests better practices in three areas: project governance, front-end planning and project execution. Keys to improvements are implementing a clear governance framework; consistently using evaluation criteria that explicitly focus relevance and sustainability; organizing projects with a role responsible for both investment and operations; and keeping focus on use value in project execution.
\end{abstract}

Keywords: Front-end planning, project execution, project governance, project organization, value creation.

\section{INTRODUCTION - STRATEGIC PROJECTS}

The strategic context of investment projects are increasingly complex due to major trends such as globalization of business and economy, increasing competition for resources, technological development, organizational integration and the speed of change. At the same time the business climate is getting more intense, requirements are getting stronger and the financial leeway has decreased compared to before the financial crisis in 2008. There is no easy way to successful projects.

A massive body of literature has emerged from research into these trends and the consequences thereof. The messages are clear: The way projects are planned and controlled needs to change [1-4]. Project management needs to be reinterpreted and redefined [5-7]. Even project management research and education has to change $[8,9]$.

Strategic projects are not about the size or complexity of the project, although typically large complex projects will often be more strategic than small, simple ones. It has to do with the perspective in which the project is developed and executed. Strategy has everything to do with how the project is directed towards achieving benefits and long term effects (outcome). A project only directed towards delivering a specific result (output) is not strategic - it is an execution project. Strategic projects are about strategic fit; finding the right concept for the solution (relevance) and implement it in a way that makes primary stakeholders benefit positively and in the long run (sustainability). These perspectives are relevant to both projects internal in an organisation (internal development projects) and projects organized for an external customer (delivery projects).

*Address correspondence to this author at the Norwegian University of Science and Technology, Trondheim, Norway; Tel: +47 735947 40;

Fax: +47 735970 21; E-mail: ole.jonny.klakegg@ntnu.no
In order to perform well in a strategic context, both the project owner and project manager have to be aware of their role and what it takes to make projects fill their strategic purpose. Only then can the project owner be sure the project organization is able to deliver the expected value for money.

In a project setting, everyone wants to be successful and create value. Not everyone succeeds. This has been documented in both public media and project management research. Prominent examples are given in $[1,2,4]$. This author believes it is possible to become much more successful at creating value, simply by increasing awareness and improving strategic approaches to projects.

Some important starting points for the reasoning in this article needs to be mentioned. Statement number 1: The intention behind initiating a project is to create value-value is a measure of success. Statement number 2: Some forms of value are more important than others. Statement number 3: We are currently not good at directing our effort towards creating the right form of value. Statement number 4: By implementing a better structure for value creation, using the right evaluation criteria, and organizing for better realization of benefits, our projects will become more valuable.

The term value is important enough to have its own line of literature. Here it is enough to refer to Bowman and Ambrosini's theory of value [10], which explains how value is created by use of resources and captured in power relationships between financial actors. A resource is not valuable in itself, only through what it can be used for.

Note that in this article a clear line is drawn between governance and management: Governors govern and managers manage. These two roles should be separated and clearly defined, they depend on each other and one contributes to the other's success. They should not be confused or mixed [11]. One consequence of this is illustrated in Fig. (6) where the organization model is shown with a very distinct diversion between them. 
A clear division between the roles on the owner/demand side and the executing party/supply side is not always apparent in project management literature. Project portfolio and program management is defined more as a scaled-up project management than something fundamentally different. Governance of projects is something quite different, as shown by Müller [12] and Klakegg [13]. Traditional project management literature will try to explain it with project management terms, but this obscures the difference. By sorting out the differences in perspectives and language on these two levels, successful projects will be easier to obtain.

By directing governance and management processes clearly towards reaching the most important success criteria; relevance and sustainability, you will become more successful at creating value. This article aims at presenting new perspectives on investment projects that helps academics and practitioners better understand what it takes to develop relevant projects with sustainable effect.

The following case story from real life illustrates some of the challenges discussed later.

\section{EXAMPLE CASE: SKJOLD CLASS - THE WORLD FASTEST PATROL BOAT}

In the mid-1990's the old patrol boats of the Norwegian Navy were getting technically outdated after many years in service. The Navy division operating the patrol boat concluded they needed a replacement and were permitted to develop a prototype which was delivered in 1999. The delivery included, not only the vessel, but also weapon systems, personnel training and equipment. Preparations immediately started for the acquisition of a series of ships in the new class. In June 2001 the Norwegian Parliament decided that these vessels should be phased into the operational structure of the Navy. In October 2003 the final decision to build and finance the vessels were made in Parliament. The delivery of 4 ships took place during the period $2008-2010$, more or less, according to budget and plan. It became known as the world fastest patrol boat reaching more than 60 knots in operation. On this level, this story looks like a fairly successful project.

Whether it is a success story depends on perspective however. Here are some additional details: The principal decision to buy the Skjold class patrol boats in 2001 was a broad political compromise. The recommendation from the Ministry of Defence was not to pursue the Skjold project further. The Chief of Defence concluded in his recent Defence Study 2000 that the investment and operating costs of the proposed fleet of fast patrol boats (FPBs) should not be prioritized, considering other investments (frigates and combat airplanes among others) and current liabilities of the Norwegian Defence. The defence material suppliers and labour unions with their intense lobbying won the politicians over to their side. The new vessels were considered by a majority of politicians to be important for Norwegian sovereignty, but also saw the opportunity to strengthen the regional employment in a troubled Norwegian ship-building industry at the time. The project gave a substantial income to Norwegian industry. In Defence Study 2007 the Chief of Defence proposed to terminate the project before completion due to the lack of financing of operations. The politicians in
Parliament decided in 2008 that the vessels should be put into operation against the Chief of Defence will, and made some budget provisions. A highly advanced bridge simulator was later installed to help the crew keep highly trained in spite of little time at sea. Due to technical changes the last two vessels were delayed several years, the last one delivered in 2012 [14].

So, how can we tell if this was a successful project? Fig. (1) looks at what it did for some of the stakeholders. The picture is simplified for the purpose of this article, more details can be found in [14-16].

\section{THE PURPOSE OF A PROJECT}

The point of this case is to make clear that a project may be both successful and unsuccessful at the same time, depending on perspective.

In a project owner perspective (the society, the corporation or an investor) the ultimate purpose of an investment is the long term creation of value. This article takes this as a starting point and investigates effective and necessary means in order to achieve the two superior criteria; relevance and sustainability ${ }^{1}$. A simple criterion of success for the project owner is; choosing the relevant concept, delivering it efficiently and with sustainable effect [15]. The relevant concept will secure the users a useful output according to their needs and priorities. The efficient delivery demonstrates success on the executing party's behalf, and the sustainable effect represents the owners' success. This article will highlight why and how.

First, let us have a look at statement number 1: The intention behind initiating a project is to create value. Value is a measure of success. What does this mean, and what are its implications?

A project is not initiated for its own sake, always to achieve something else. The project is not an objective, it is a tool. The real purpose normally lies far beyond the result it produces (a new product, service, organisational change etc.). For some parties making money may be the fundamental motivation for initiating the project. Other parties may be looking for long term changes and effects that follow from having a new situation.

All projects are about change. The motivation for projects is that the intended situation after the project is perceived as better (more valuable) than the situation before the project is executed.

Projects are also full of dilemmas such as building a new road; it utilizes valuable space, limited resources, and may also contribute to environmental problems in order to create the new asset. Logically it is not initiated to destroy existing values, but to create something of higher value we might have to make sacrifices, give up something of value during the process.

Value creation can be seen as the one superior goal of all professional activity, but value is not the same for everyone.

\footnotetext{
${ }^{1}$ The OECD criteria for evaluation of projects are: Efficiency, Effectiveness, Impact, Relevance, and Sustainability [17]. The two superior criteria, relevance and sustainability, can to some extent compensate for lack of success in the three others, but not the other way around.
} 


\begin{tabular}{|l|l|l|}
\hline \multicolumn{1}{|c|}{ Stakeholder } & Initial Position & Outcome \\
\hline \hline Project organisation & Positive & $\begin{array}{l}\text { Great success, delivered a technically challenging system within budget, } \\
\text { cost approx. 600 million EURO. Seems well performed as an acquisition } \\
\text { project, although the two last vessels were delayed. }\end{array}$ \\
\hline $\begin{array}{l}\text { Ship-builders and supplier } \\
\text { consortium }\end{array}$ & Positive & $\begin{array}{l}\text { Success as far as this project goes. Unique technology developed and } \\
\text { delivered. However; the market is very limited. A civil version is } \\
\text { developed to gain new market. }\end{array}$ \\
\hline Labour unions & Negative & $\begin{array}{l}\text { Great success in turning the politicians in favour of the project against } \\
\text { recommendations of the defence. The local ship-building industry is still } \\
\text { working, creating jobs. }\end{array}$ \\
\hline $\begin{array}{l}\text { The Ministry of Defence } \\
\text { and the Chief of Defence }\end{array}$ & Positive & $\begin{array}{l}\text { Failure to convince the politicians that this was not the right project. } \\
\text { operational matters. }\end{array}$ \\
\hline The users of the vessels & $\begin{array}{l}\text { They did get a new, better vessel than the old one. They are not able to } \\
\text { operate it as much at sea as they want. Partly success, partly failure. }\end{array}$ \\
\hline Norwegian industry & Positive & $\begin{array}{l}\text { Success. The project demonstrates world class capacities in Norwegian } \\
\text { industry, and the project gave 130 million EURO repurchase income in } \\
\text { the short term. }\end{array}$ \\
\hline $\begin{array}{l}\text { The politicians in } \\
\text { Parliament }\end{array}$ & $\begin{array}{l}\text { They succeeded in forcing the Defence to do an investment they did not } \\
\text { want and then to operate it. A successful demonstration of power. They } \\
\text { did manage to secure the jobs of a local ship-builder for the time being. }\end{array}$ \\
\hline Society & $\begin{array}{l}\text { The politicians made decisions in this case that waste a big amount of } \\
\text { public finances - taxpayer's money was spent on a defence project that } \\
\text { did not really deliver increased capacity to secure sovereignty. There is } \\
\text { good reason to look at this project as a complete failure in this } \\
\text { perspective. }\end{array}$ \\
\hline
\end{tabular}

Fig. (1). Stakeholders and their outcome from the Skjold class project.

So, we have to ask what value is? value for whom? and what the consequences are for how we govern and manage our projects?

Start by thinking of value in an economic sense: Value is measurable in monetary or other terms. Economic theories study how prices for goods and services are established and maintained, the exchange value. Exchange value is important to understand the relations between the parties involved. Management theories look at the added value from activities and how they are performed. Added value is close to the fundamental purpose of any project. These aspects of value have implications for governance and management related to projects.

Value is subjective; one thing may have different value to one individual or organization, and a different value to others. This leads to the question about value for whom? Many authors studying governance discuss differences between countries and the governance systems found in different countries. There seems to be two important categories of corporate governance systems [13, p. 206]:

○ Shareholder-value systems (USA, UK, Canada, etc.)
- Communitarian systems (Central and Northern Europe, Japan, etc.)

The main difference concerns who is regarded as legitimate stakeholders. The shareholder-value system only regards shareholders as legitimate stakeholders. The communitarian value systems allow other stakeholders in society to have legitimate interest in what a corporation does. Only the communitarian governance system opens up for the "value for whom" discussion. The shareholder-value system does not. For the purpose of the discussion in this article we need to consider many parties as legitimate stakeholders in projects.

Samset [18] gives a useful contribution to answer the "value for whom" question. He makes it clear that value has to be seen in a very wide perspective (society, the owner, investor or financing party). Further, the value of an investment has to be seen as the value that the effect of using the results have for the end users. The value for users is clearly different from that of society or the investor. The third level of value perspectives is that of the executing party - the creator of the results (suppliers). The value for 
executing parties is very different from that of owners or users.

Success has to be evaluated in all these three perspectives and might give completely different answers in each perspective. This explains why an investment may be a success or a failure independent of whether the users are satisfied or the project has overspent budgets and is delivered too late. Real success, however, is when the executing party has performed a good project (made money, delivered on time and budget), the users are happy with the effect of using the result (functions, capacity as needed) and the owner and financing party has a good return on investment in the short and especially the long term (financially, goodwill, and other aspects). Fig. (2) illustrates the value concept on three levels in three different cases.

The examples in Fig. (2) illustrate a wide array of success measures that may be useful in considering potential value of a future project, and to what degree the project is a success in the three fundamental perspectives. Our ability to create value depends on how well we choose projects that have a potential to be valuable to suppliers, users and owners at the same time.

Another challenge is value changes over time. What has a certain value at one point in time may have a completely different value at another point in time. "Haute Couture", fashion and other examples of passing fancies may illustrate the effect. We know that demand is normally quite elastic, what people are willing to pay for a certain product or service changes over time. The willingness to pay is one way of measuring value. The same effect is also affecting things that are freely available, like fresh air. In earlier times when fresh air was plentiful no one really thought about its value. In modern times fresh air has become limited and people are more aware of its importance, thus we value it more now and may be willing to investing keeping what is left of it.

It is the same with location - what is extremely valuable in one place might not be so valuable in another. This often has to do with availability of the item or resource, and its perceived importance in certain cultural settings. With these challenges in mind, let us have a look at how we can logically reason about the value of projects.

\section{REAL VALUE DEPENDS ON RELEVANCE AND SUSTAINABILITY}

Here we will look into statement number 2: Some forms of value are more important than others. We need to consider two concepts, here defined by the Organisation for Economic Co-operation and Development [19]:

"Relevance is the extent to which the project is suited to the priorities and policies of the target group, recipient and the financing party." Relevance represents a connection between activities in the project, their results and outcomes and the purpose. If the activities produce results that is not what the users wants or needs, or if results do not comply with the requirements set up by the owner or financing party - then your project does not produce the right solution. The result will not be used as intended, and thus the intended value will never be generated.

"Sustainability is concerned with measuring whether the benefits of the project are likely to continue after its completion. Projects need to be environmentally as well as socially and financially sustainable." According to OECD, sustainability is the "final test" of the success of development projects. Sustainability needs to be studied in a time frame that extends far beyond that of the project itself. Sustainability depends on what happens outside the project and in long terms, e.g. another product might come and take its place in the market, or a financial crisis might reduce the financial ability to keep up the demand for the infrastructure produced by your project.

Klakegg [20] discussed these concepts and concludes that relevance and sustainability are associated with the perspective of the owners and users, whereas efficiency is associated with the executing party's perspective. He finds that the most important challenges at the front-end of projects is to secure relevance and sustainability because these two criteria are critical in the sense that if a project ends up not fulfilling them it has failed, no matter how well it has performed with respect to other criteria like efficiency and other impacts. If a project performs well with respect to relevance and sustainability this may compensate for lower performance with respect to the remaining three criteria in the OECD Integrated evaluation model, with the possible exception of some impacts.

\begin{tabular}{|c|c|c|c|}
\hline Examples: & Perspective: & User & Owner/Financing party \\
\hline \hline $\begin{array}{c}\text { Developing a new product } \\
\text { (private sector) }\end{array}$ & $\begin{array}{c}\text { Developing new } \\
\text { technology, solve a } \\
\text { problem. }\end{array}$ & $\begin{array}{c}\text { New possibilities, better } \\
\text { ways to fulfil needs, } \\
\text { increased status. }\end{array}$ & $\begin{array}{c}\text { Making money in short and } \\
\text { long term. }\end{array}$ \\
\hline $\begin{array}{c}\text { Building a new school } \\
\text { (public sector) }\end{array}$ & $\begin{array}{c}\text { Delivered according to } \\
\text { contract. Making money } \\
\text { doing it. }\end{array}$ & $\begin{array}{c}\text { Good working conditions } \\
\text { (light, air etc.). Reduced } \\
\text { energy cost. }\end{array}$ & $\begin{array}{c}\text { Better education for the } \\
\text { students, better candidates } \\
\text { for society. }\end{array}$ \\
\hline $\begin{array}{c}\text { Disaster aid project (not for } \\
\text { profit sector) }\end{array}$ & $\begin{array}{c}\text { Be of assistance to those in } \\
\text { need, to learn. }\end{array}$ & $\begin{array}{c}\text { Immediate relief, have basic } \\
\text { needs catered for. }\end{array}$ & $\begin{array}{c}\text { Avoid breakdown of } \\
\text { society, restore stability. }\end{array}$ \\
\hline
\end{tabular}

Fig. (2). Examples of different values in different perspectives. 
Dinsmore and Ribeiro [21, p. 1] reached a similar conclusion: 'While good project management cannot save an organization from a bad strategy, bad project management may harm a good strategy.' Miller and Lessard [1, p. 13] states: 'Once built, the project has little use beyond the original intended purpose. If it meets real needs, it might be useful for many years to come. But even so, such usefulness does not guarantee financial success.' The whole basis for a successful project is whether there is a need for it and whether there is a long term benefit following from the result. If this basis is not there, the project should never be allowed to start.

Hence, the focus should be on the two superior criteria, relevance and sustainability. This does not imply other criteria are unimportant, as they can certainly also create failure. In this strategic perspective, 'unsuccessful' is the label used for projects that are not useful and/or not sustainable in the longer time perspective.

The unstable nature of value represents a real problem for strategic projects. As availability and priorities change over time, the target for the project also moves. This may have some severe consequences. We cannot automatically expect projects to stay in line with priorities over time, even if it is well planned from the start and has a limited timeframe.

Kreiner [22] asked key questions: What happens to the project's value as the environment of the project drifts? How can it keep its relevance in a changing environment? The fundamental assumption is that the project environment may be changed over time. The originally intended outcomes may not remain relevant over time, so relevance erodes. He discusses several strategies that the project manager may choose to rely on, based on networks or hierarchical approaches. Nevertheless he concluded that no matter what the choice is, the project manager will be held accountable. Kreiner was the first to explicitly relate relevance to the value creation in projects. He illustrates the combat between traditional project management (risk reduction) and the purpose of the project (value creation) in the continuous battle over "spec freeze" and "spec float". Kreiner observed that a traditional view is that the project manager is not responsible for value creation, only for creating the specified project results.

Thiry [23, p. 3] shows how the traditional value distribution focus of shareholder models in corporate governance should be replaced by a stronger stakeholder value focus in a strategic value creation model. This, he claims, will lead to a stronger focus on sustainable results and effectiveness. He puts focus on what investment alternatives are chosen and to which stakeholder or group's benefit. Looking at how corporate governance and projects is connected, he identifies [p. 1] two main directions in current organisational literature, and one recently emerging:

- It is the business of business to make money, and therefore to pursue shareholders' interests.

- Companies exist to serve the interest of multiple stakeholders.

- Value creation through innovation and intangible assets.
Thiry argues that the shareholder model is short-sighted and disregards the consequences of a changing economic environment. Both the corporate view and the project view identify stakeholders as actors significant for successful realisation of objectives. Thus he concludes that businesses currently focussing the shareholder model will likely favour a stakeholder approach in the future and that they should aim for value creation. Recently, authors have criticized both the shareholder and stakeholder perspective to focus too much on utilizing existing productive resources and too little on increasing or transforming them - see Fig. (3).

With the traditional shareholder value model the focus will continue to be on short term results, financial measures, vertical control, and efficiency (doing the same things better). With the emerging value creation perspective, focus will shift to stakeholder value, sustainable results, organisational measures, empowerment and creativity, and effectiveness (doing different things to create more value). Thiry [23, p. 3] argues this wider set of success criteria will bring an increased focus on the link between expected benefits and results.

We have in this section established a logic that concludes that some values are more important than others. In the strategic perspective, the most important criteria are relevance and sustainability. Relevance keeps the users happy and makes them willing to embrace the result (outputs) of your project. This is a necessary prerequisite for having the intended effect and for creating benefits at all. Then, as a final test; does the intended effect last? is it sustainable? Can it keep producing the intended benefits (outcomes) over time without exceeding limitations in social, environmental or financial perspectives? The project is certainly a failure in the strategic perspective if it does not give long term benefits to owners and financing party. In the next section we will look at where we currently stand on some of these matters.

\section{TRYING TO COPE}

We turn to look at statement number 3: We are currently not good at directing our effort towards creating the right form of value. Let us look into current practice; how are we coping with the quest for value creation? What are current practices and why do we not succeed? One main question, given the conclusion to the previous section is; how well do we approach the superior criteria relevance and sustainability? Some evidence of the current situation is presented lately:

Klakegg [20, p. 142] documented the result of a survey on what considerations are made when defining objectives for public projects. The considerations include elements similar to evaluation criteria, and ranked them according to the frequency of use. The result in descending order: Impacts, Resources, Realism, Uncertainty/Risk, Effectiveness, Relevance, Efficiency, Sustainability, Causality and Level of ambitions. The respondents mention other considerations actually used: Strategic fit, Use of available funds, Environmental and social cross-impacts, Politicians' image, Beneficiaries, Ability to achieve political objectives. All of the mentioned criteria are purposeful and logical, important in certain settings. 
Traditional

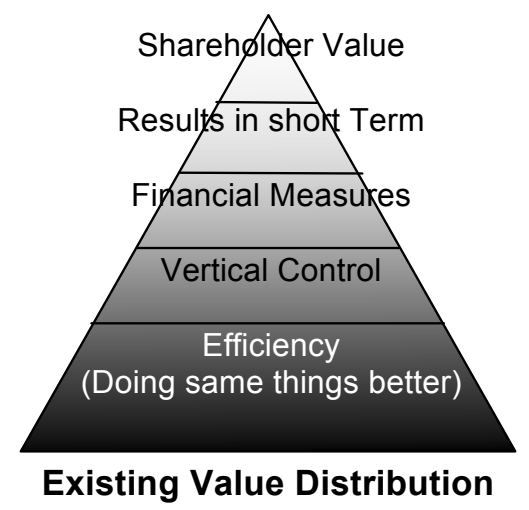

Emergent

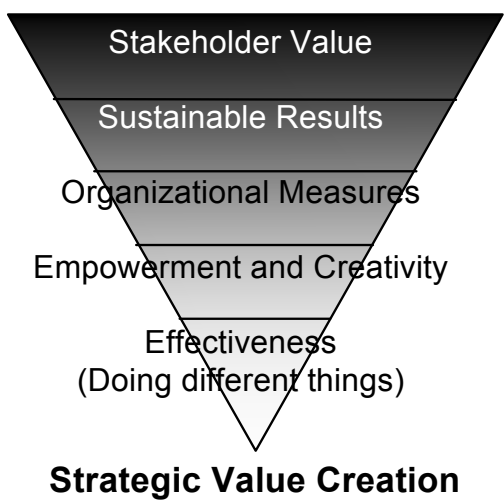

Fig. (3). Shareholder and stakeholder value approaches to value creation. Adapted from Thiry (2006).

The 76 respondents were all experienced senior personnel working in the front-end of major public projects. Most people involved in projects are not experts, and this is true for public, private and not-for-profit sectors alike. The answers are likely to show a more professional profile than real life in small and medium size project. Still, the respondents demonstrate a tendency towards the narrow and short-sighted resource limitation perspective, combined with an adverse decision making behavior focusing realism and avoiding uncertainty. The answers show no clear direction as to what is actually important to achieve. An interesting observation is that planners in more than $50 \%$ of cases do not consider relevance and sustainability. When asked directly what could be done to make sure relevance and sustainability are considered, the obvious answer came out; you have to make relevance and sustainability explicit evaluation criteria.

With the awareness that relevance and sustainability is the most important criteria for the project to meet its purpose, it seems natural to ask why then relevance and sustainability is not well taken care of in practical projects. A survey [20] asked for the most important problems in the front-end of projects related to relevance and sustainability and gave the following results:

\section{There is lack of relevance because}

- Needs are unknown, misunderstood or ignored. The reason behind this is identified as needs are ignored by planners and decision makers due to the political or personality reasons.

- The objectives of the project are unknown or misunderstood. The reason behind this is that the objectives of the project are not stated at all or are expressed in a very unclear manner.

These results show that there is a mixed challenge here. The situation may be improved by relatively simple means like improving the planning and decision making procedures with clear requirements for documenting needs and objectives. Involving the stakeholders in these processes is one key to a successful front-end phase. The political and personality reasons are much more difficult to handle. It is difficult to change people. However, one relatively simple way of reducing the available space for hidden agendas based on personality or political reasons are using independent third party assessments. For critical and complex projects this should be obligatory.

There is lack of sustainability because

- There is conflict over objectives and/or strategies concerning the project. The reason behind this is that conflict over priorities between stakeholders are neglected and not solved early.

- There is lack of commitment among key stakeholders. The reason behind this is not identifying that there is little support for the project outcome in the owner and financing party organizations.

- $\quad$ Economic and financial benefits are low, compared to investment and operational cost. Also business conditions change between the concept stage and final delivery. The reasons for these problems are found in the planning optimism, costs are often estimated too low and benefits estimated too high. This may mislead the decision makers, deliberately or not.

The challenges concerning sustainability are very complex and therefore the experts are not able to point to one or two dominating reasons, or solutions for that matter. It is difficult to see into the future, the uncertainty is real and we need to learn how to live with it. Well structured planning and decision making processes with well defined roles and responsibilities are vital, as is transparency in these processes. Identifying and actively confronting conflict material is of great importance. Leaving it untouched, hoping it will go away, only gives it time and space to grow stronger.

The only real weapon against planning optimism is incorporating the external view [3]. Taking an external perspective on what we do is useful, but not enough. Having an independent third party go through the documentation of the project and make their own assessments can provide decision makers with a realistic and complete basis for their decisions.

Klakegg [20, p. 136] looked into the logical structure and probability for success in the front-end of public projects. He found evidence that this is seldom an issue and found strong 
indications of the consequences. By analyzing in detail all objectives defined in a sample of 51 major public investment projects in Norway the result shows that:

- Only $31 \%$ of the projects were logically well defined in terms of causality, realism, and consistency.

- $24 \%$ of the projects were ill defined in the sense that they were not complete; one or more of the perspectives owner/society, user or executing party was missing.

- $\quad 45 \%$ of the projects were characterized by objectives that mirror the political/strategic process and not the logic of the project. This typically results in a wide array of objectives attached to the project, of which many have no or little connection to the project at all.

Further studies by this author have revealed that there is no reason to expect much better results in private or not-forprofit sectors either. If this is going to improve, the obvious thing to do is to put focus on the fundamental logic of projects, and to do this early in the development of the conceptual solution. By the time the project is developed into a fully documented proposal for financing it is too late. At that late stage, there will be too much political and emotional interest invested in the proposed projects. "Love makes blind" is true, also when it comes to projects.

One could easily use these results as arguments why projects fail, and continues to do so. If one looks more carefully on the "value for whom" issues, the picture becomes more nuanced. As illustrated in the initial case story, the question of success and failure may have many colors and shades.

\section{HOW TO MAKE REAL VALUE CREATION POSSIBLE}

Statement number 4 says: By implementing a better structure for value creation, by using the right evaluation criteria, and by organizing for better realization of benefits our projects will become more valuable. This section looks at these three areas and suggests good practices on each of them. These suggestions might not be the only available choices to create valuable projects, but they do include elements that will improve the situation compared to established practice today. By focussing governance- and management processes clearly towards the most important values, we will become more successful at creating value from projects.

Fig. (4) illustrates three different perspectives on projects that must be considered as main areas for improvement. In this section some suggestions are given that will make us able to increase our rate of success.

Fig. (4) is consistent with the principal division between governance and management as argued earlier, and points to the very different characteristics of the front-end compared to the execution phase of projects.

\subsection{On Governance Level: Installing Better Governance Frameworks}

The development and implementation of governance frameworks for projects is described in several sources [13, $14,24]$ and may be associated with the term institutional framework. The purpose of a governance framework is expressed through its definition:

A governance framework for projects is "a set of principles and an organized structure established as authoritative within an institution, comprising processes and rules established to ensure projects meet their purpose." [13, p. 29].

This logical structure address all the elements discussed above and makes them come together in a framework that every organization dealing with projects should have. Characteristic elements of governance frameworks are:

- The business model for the corporation/organization (strategic perspective)

- The clarity in roles and responsibilities (governance and accountability)

- The governance principles (common world view, rules of conduct)

- $\quad$ The use of policy instruments (command and control, support and empowerment)

- $\quad$ The decision making process structure (organization levels, reporting lines)

- $\quad$ The project model (phases and processes, temporary organization)

- The stage gates and assessments (arenas for coordination, requirements for documents).

Some of these bullet-points are obvious and already a part of current practice, but still there is reason to comment on some important issues raised in recent research.

The business model is key to understanding any organization. It gives purpose to the whole being of the organization and thus also its projects. In any project, the project owner's business model must be reflected in the delivery organization's (project organization's) business

Project governance:

Governance frameworks and assessments

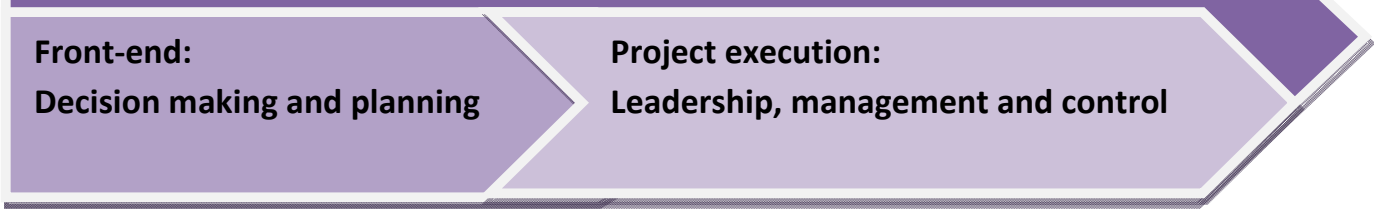

Fig. (4). Three perspectives on projects - three improvement areas. 
models [25, p. 123]. The reason is that the value itself comes from the owner and users. In a market situation this implies that the value must be the primary focus of the project organization.

Arge and Hjelmbrekke [25, p. 125] looks at delivery projects and suggest interpreting the business model into a value model for the project - a systematic approach to a value creation culture. It should reflect the owner's expectations of value creation and how the delivery organization is expected to solve the problems for internal and external benefits. The focus should be on use value. Value for the users and owners from the use of the project delivery will also be the basis for assessing the result's exchange value. The design and production strategy of the delivery organization (executing party) should also be aligned with the owner's business model. They present a governance model framework that may enable both the demand side and the supply side to focus the on both effectiveness and efficiency related to project goals.

Two important issues stand out in this contribution:

$\bullet$

Awareness that the delivery organization in delivery projects are not a part of the owning organization and thus cannot automatically be expected to align with the owner's strategies. By using business models as a tool for alignment this fundamental challenge can be overcome.

- The importance of use value (effect goals relevance) as the primary focus of the project organization, and its connection to business models. This strategic perspective is vital to the value creation in projects.

- The governance principles explain how the organization is supposed to work. The purpose is to establish a common reference for behavior in the organization. Realizing that control may not be the best way to influence individuals, there needs to be a clear balance between governance instruments like information (advice and warnings) and motivation ("carrot and stick") [26]. The underlying purpose of governance principles are reducing risk of unwanted behavior and increasing the probability of intended behavior in the organization. The governance principles may include differentiation between different categories of projects - so it might also have a situational nature on this level [24, p. 73].

Among the important issues embedded in the governance principles are mechanisms to reduce complexity and to distribute risk among the participants in projects. Other important elements are the mechanisms that trigger governance processes in response to turbulence in the project environment and complex social learning. Without these, the organization is not likely to succeed in the long run. The underlying issues here are the need for governance to spread from the top of the organization down to the operational activities, and accountability to rise up from the bottom to the top. Establishing good governance and accountability to be trusted are major success factors for all organizations, not least in projects.
The governance framework includes the structural elements that make up the skeleton of the organization. Hierarchical organization levels, decision making processes and reporting lines need to clarify roles and responsibilities. Typically the framework addresses projects in terms of phases and decision gates. Important tools are the project models including its principles and processes, not least how to set up a temporary organization (project organization).

Furthermore, the stage gates and assessments offers arenas for coordination of the participating parties, and it helps secure the right quality in the basis for making decisions (primarily the quality of documents). It is important to specify requirements for the way the organization shall control its professional quality and presents alternatives to the decision makers, e.g. requirements for how to set up a business case.

The governance framework needs to secure responses when conditions change, and it contains the mechanisms that helps the organization make the right decisions, i.e. controls and requirements. Fast decisions when this is called for.

The governance framework meets the project management system in common structures, principles and practices. The governance framework and the management system need to be well aligned.

\subsection{In the Front-End: Using Consistent Sets of Project Evaluation Criteria}

Using a consistent set of evaluation criteria is vital to the creation of purposeful initiatives, such as choosing the right. As shown above, it is important for the over-all result that the superior criteria relevance and sustainability is used as explicit evaluation criteria in choosing concepts for solutions and evaluating projects before, during and after the execution of the project: Klakegg [13] documents that this is seldom done.

Finding a consistent set of criteria is difficult, but one possible solution is the OECD integrated evaluation criteria [17]. This methodology is designed for development projects in the public- and not-for-profit sectors, but is equally useful for private sector for strategic and complex projects. Using these criteria in the front-end will secure that the most important issues are addressed. These criteria should be used in a combination with carefully chosen assessment methods and tools that give support for development of purposeful strategic projects. Fig. (5) indicates possible combinations of criteria and types of assessments that are appropriate in a complex project. These are not the only possible combinations or tools, but together they make up a strong methodological approach to projects in the front-end.

The OECD integrated evaluation criteria is complex and several of the suggested types of assessments mentioned in Fig. (5) require special competence. This may be too much to handle for some organisations. It might also be too resource demanding for small and medium sized projects. In any case it is still important to remember what helps us create more value; achieving relevance and sustainability. The most important thing is asking the right questions.

Any simplified criteria should have relevance and sustainability as a starting point. Do not start with the short- 


\begin{tabular}{|l|l|}
\hline \multicolumn{1}{|c|}{ Criteria } & \multicolumn{1}{c|}{ Types of Assessment at Pre-Project Stage } \\
\hline \hline Relevance: & System analysis, Need analysis, Risk and consequence analysis, Alternatives analysis \\
\hline Sustainability: & Environmental impact study, Future studies \\
\hline Impact: & Projected benefit analysis, Risk and consequence analysis \\
\hline Effectiveness: & Project cost estimates, Alternatives analysis \\
\hline Efficiency: & Cost/Benefit analysis, Alternatives analysis \\
\hline
\end{tabular}

Fig. (5). Front-end assessments of complex projects (Klakegg 2010, p. 331).

sighted criteria like realism and avoiding overspend, reducing uncertainty and risk. These will hamper your ability to achieve maximum value. They express necessary limitations that should come in second line.

\subsection{For execution: Organizing for Good Governance of Projects}

To create good results, someone in the owning organisation needs to be responsible for the initiative. Having an individual accountable for the project is crucial. This individual is often said to be "the owner of the business case", and thus responsible for how the resources are spent and what benefits come out of the initiative. In UK public projects (OGC referred in [13]) this individual is called the Senior Responsible Owner (SRO), an individual accountable for reaching goals and delivering benefits. Prince2 (UK) puts the name "Executive" on the SRO [27], American literature

\section{Single execution project}

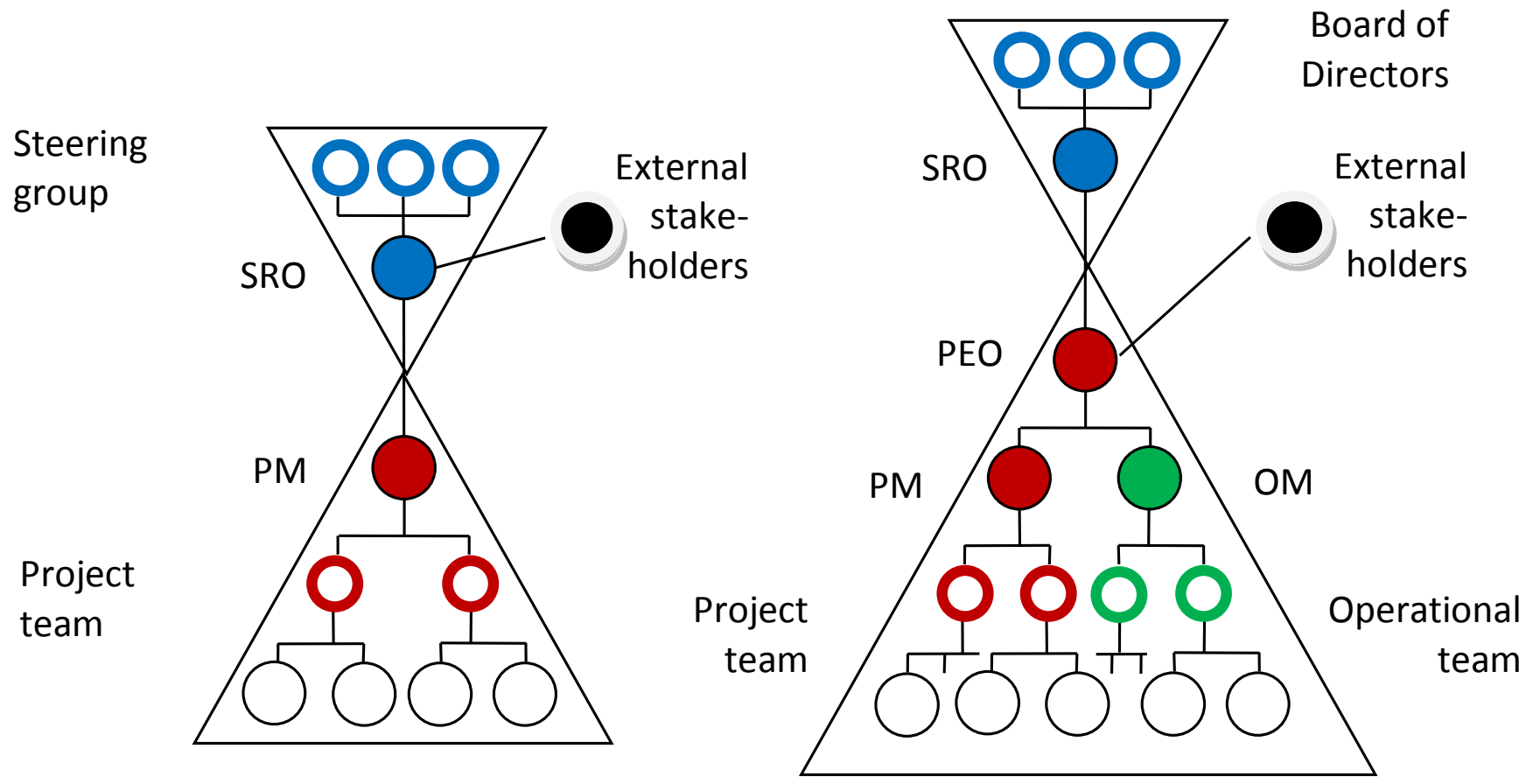

refers to the "Sponsor" [28]. This is the formal point of contact between the owner and the delivery organisation for decisions. Obviously, the mandate of the SRO is important.

There are many ways of organizing projects in the execution perspective. When the issue is organizing for good governance of projects, two basic models come forward. They are illustrated in Fig. (6). The idea for the model of the strategic program/project model on the right hand side of Fig. (6) is adapted from Rolstadås et al. [29, p. 83].

The single execution project has a narrow perspective and is only installed to deliver some sort of specific deliverables. From a project perspective this is fascinatingly simple, and has made projects the most popular way of organizing an operational task.

From a governance perspective, however, this is not so simple. The project manager (PM) and project team delivers a solution that someone has defined and then leave. Someone

\section{Strategic program/project}

Fig. (6). Organizing for good governance of projects. Two project models. 
else is going to utilize the results and take responsibility for value creation. This is asking for sub-optimization, and one fundamental reason why many projects still fail, even when using a professional PM. Even good PMs may have their personal agendas that may lead to sub-optimization. Please note that the most important and crucial agenda for the PM is created by the owner; how the project will be judged as a success or failure.

The single execution project model can work, but this requires that the project is well integrated in the permanent organisation. If it is not well integrated, there is a large risk of delivering the wrong results, or that the permanent organisation is not prepared when the result is delivered. In a situation with an external delivery organization this integration is challenging for many reasons. An obvious one is the fact that the externals have their own motherorganization's wellbeing to think about. It is basically a question if they are in a position with freedom to hold the project objectives higher than their own goals. You need to look at their mother company's culture and ideology to consider this, as discussed in [25].

The SRO is responsible for the Business Case (UK definition). This makes him or her responsible for defining the project goals (including capability to be delivered) and the strategy for delivery. This limits the PM's responsibility to produce the deliverables (often described as doing the project right). The definition also makes the SRO responsible for making the owner organisation able to capture the benefits from the deliveries created by the project. Experience tells us that the delegation of responsibility to prepare the operational organisation to capture the benefits is often left unclear too long. This is unnecessary.

For good governance, the single execution project model should include a direct single-link between the SRO and the Project Manager (PM). The single execution project model will never work well unless the SRO is very skilful, has the right mandate and plays his role actively, displaying leadership not only towards the project, but also towards the permanent organisation and other stakeholders.

The strategic program or strategic project is different because it is installed to create value in itself. The most fundamental difference is that the responsibility for value creation becomes a part of the project process. All three fundamental stages: (1) Defining goals and necessary capabilities, traditionally the focus at the front-end. (2) Project execution, and (3) Value capture, which happens primarily in operations, need to be included in the strategic program or project. From a project perspective this is more complicated. Here the project organisation has to have a much wider perspective and take a bigger responsibility.

So, why would we want this complicated construction? Obviously, to make sure we develop the right project and spend the right amount of resources in the front-end to make sure we have the optimal investment in a life-cycle perspective - one that is optimal in the operational phase. Only with continuity in organisation and a wide perspective can we avoid sub-optimizing.

To avoid sub-optimization the project organisation needs one key role on top of the organisation on the delivery side to make the right, balanced decisions in a life-cycle perspective. This is not the SRO, because the SRO is on the owner's side as shown in Fig. (6). This individual with full responsibility for the development on the delivery side is important; we can call this role Project Executive Officer (PEO) as suggested in [29]. This role may partly be recognized in titles like Program Director or Project Director. An alternative description could be a "strategic project manager" but that might give wrong associations. This new role will give strategic projects a stronger position to create value than current practice based on a diversion between the project delivery and the value creation. to:

Rolstadås et al. $[29$, p. 82] concludes that the PEO need

- Possess skills and experience needed to manage the owner's role in the project.

- Maintain direct access to the people making key decisions.

- Be vested with authority to take day-to-day executive action

- $\quad$ See the project through (from the definition phase my insertion) to completion

In the strategic project model we should see two key roles on the level below the PEO: The project manager (PM) responsible for developing the new solution (often a physical artefact or new system), and the operations manager (OM) responsible for integrating the new solution into the operational organisation. Both PM and OM have a team working under them to develop, produce and implement solutions. These teams may be integrated. OM's will often be functional leaders. PM and OM needs to be well coordinated. On their level there might be conflicts over solutions and resources, but they know where to go for a decision when they cannot solve it by themselves: the PEO.

\section{CONCLUSION}

This article's starting point is that the strategic dimension has to do with creating value. Important shortcomings identified; short-sighted planning, not addressing relevance and sustainability, not addressing the structural logic of the project in the front-end, using the wrong mix of approaches to project governance. To enhance value creation in projects this article suggests better practices in three areas: project governance, front-end planning and project execution.

On project governance level it is vital to implement an effective governance framework in the organization. The purpose of such a framework is to give structure to the way projects are initiated, executed and benefits harvested. The decision making process and the project model with its stage gates and assessments are key elements. The most important suggestions in this area is the use of business models as tool for alignment in delivery projects, and the importance of focusing use value as primary focus in project execution.

In the front-end the most important issue is to secure that good basis for decisions about the future projects is established. Further, it is of vital importance how projects are defined and designed in order to achieve their strategic purpose. This is where relevance and sustainability comes in. 
The most important suggestions in this area is the use of a consistent and integrated evaluation criteria that explicitly focuses relevance and sustainability, and to avoid limiting short-sighted criteria like realism, resource limitations and risk minimizing in the early decisions as this will potentially hamper value creation.

In project execution the strategic project needs a responsible role that represents both the project (investment) and the operations (value creation) and represent continuity from definition to completion. The individual in this position needs relations, strong mandate and necessary formal position to be able to install good project governance and influence project premises. If this is achieved, the potential for value creation will be significantly improved compared to current practices.

\section{CONFLICT OF INTEREST}

The author confirms that this article content has no conflict of interest.

\section{ACKNOWLEDGEMENTS}

Most of the research behind this article was financed by the Concept research program: www.concept.ntnu.no.

\section{REFERENCES}

[1] Miller R, Lessard DR. The strategic management of large engineering projects: shaping institutions, risks and governance. Cambridge: Mass, MIT Press 2000.

[2] Flyvbjerg B, Bruzelius N, Rothengatter W. Megaprojects and risk; an anatomy of ambition. Cambridge: Cambridge University Press 2003.

[3] Williams T, Sunnevåg K, Samset K, Eds. Making essential choices with scant information. Palgrave Macmillan, UK: Basingstoke 2009.

[4] Merrow EW. Industrial megaprojects. Concepts, strategies and practices for success. Hoboken, New Jersey, USA: John Wiley and Sons 2011.

[5] Shenhar AJ, Dvir D. Reinventing project management. The Diamond approach to successful growth and innovation. Boston, Mass, USA: Harvard Business School Press 2007.

[6] Andersen E. Rethinking project management: an organisational perspective. Prentice Hall, Harlow, UK: Harlow Education Ltd 2008.

[7] Morris PWG. Reconstructing project management. John Wiley and Sons. Chichester, UK: Wiley-Blackwell 2013.

[8] Cicmil S, Williams T, Thomas J, Hodgson D. Rethinking project management: researching the actuality of projects. Int $\mathrm{J}$ Proj Manage 2006; 24(8): 675-86.

[9] Thomas J, Mengel T. Preparing project managers to deal with complexity-advanced project management education. Int $\mathrm{J}$ Proj Manage 2008; 26(3): 304-15.
[10] Bowman C, Ambrosini V. How value is created and destroyed. Euro Bus Rev 2010; 22(5): 479-95.

[11] Otto S. Not so very different. A comparison of the roles of chairs of governing bodies and managers in different sectors. In: Comforth $\mathrm{C}$, Ed. The governance of public and non-profit organizations. What do boards do? Ruthledge studies in the management of public and non-profit organizations. Ruthledge 2005, pp. 133-49.

[12] Müller R. Project governance. Fundamentals of project management series. Farnham, UK: Gower Publishing Ltd 2009.

[13] Klakegg OJ. Governance of Major Public Investment Projects. In Pursuit of Relevance and Sustainability. Doctoral thesis at NTNU, 2010: 15. Norwegian University of Science and Technology. Trondheim, Norway. Available at: http://urn.kb.se/resolve?urn=urn :nbn:no:ntnu:diva-6887

[14] Umoe Mandal Ship builders' webpage: http://www.um.no/WEB /um200.nsf/pages/Home (last approached 11.09.2014).

[15] Klakegg OJ, Williams T, Walker D, Andersen B, Magnussen OM. Early warning signs in complex projects. Newtown Square, USA: Project Management Institute 2010.

[16] Volden GH, Samset K. Etterevaluering av statlige investeringsprosjekter. Konklusjoner, erfaringer og råd basert på pilotevaluering av fire prosjekter. [Post-evaluation of State financed investment projects], 2013. Concept-report no. 30. Available at http://www.con cept.ntnu.no

[17] OECD. Development Assistance Committee (DAC), Draft standard on Development Evaluation 2006. Available at: http://www.oec d.org

[18] Samset K. Project evaluation. Making investments succeed. Trondheim, Norway: Tapir Academic Press 2003.

[19] OECD. Glossary of Key Terms in Evaluation and Results Based Management. Development Assistance Committee. Organisation for Economic Co-operation and Development 2002. Available at: www.oecd.org

[20] Klakegg OJ. Pursuing relevance and sustainability: Improvement strategies for major public projects. Int J Manag Proj Bus 2009; 2(4), 499-518.

[21] Dinsmore PC, Ribeiro PC. Corporate governance and strategic projects. PM World Today 2007; 9(4).

[22] Kreiner K. In Search of relevance: project management in drifting environments. Scand J Manage 1995; 11(4): 335-46.

[23] Thiry M. Governance trends and issues (undated paper). 2006.

[24] Klakegg OJ, Williams T, Magnussen OM. Governance frameworks for public project development and estimation. Newtown Square, USA: Project Management Institute 2009

[25] Arge K, Hjelmbrekke H, Eds. Value enhancing processes in building and real estate. Proceedings of the joint CIB W070, W092 \& TG72 International conference. Cape Town, South-Africa: delivering value to the community 2012 .

[26] Bemelmans-Videc M, Rist R, Vedung E, Eds. Carrots, sticks and sermons: Policy instruments and their evaluation. New Jersey, USA: Transaction Publishers 1998.

[27] Directing Successful Projects with PRINCE2. UK: Axelos - Global best practice 2009 .

[28] Crawford L, Cooke-Davies T, Hobbs B, Labuschagne L, Remington K, Chen P. Situational sponsorship of programs and projects: An empirical review. Newtown Square, USA: Project Management Institute 2008.

[29] Rolstadås A, Hetland PW, Jergeas GF, Westney RE. Risk navigation strategies for major capital projects. Beyond the Myth of Predictability. Springer 2011. 